Benha Veterinary Medical Journal
Official Journal Issued by
Faculty of
Veterinary Medicine Journal homepage: https://bvmj.journals.ekb.eg/

Original Paper

\title{
Quality indices of some ready-to-eat meat products
}

Sabry, Reham ${ }^{1}$, Hassan Ahmed Mohamed ${ }^{1}$, Zaghloul marionette ${ }^{2}$, Ibrahim, Hemmat Mostafa ${ }^{1}$

${ }^{1}$ Food Hygiene Department, Faculty of Veterinary Medicine, Banha university

${ }^{2}$ Food Hygiene Dept., Animal Health Research Institute, Benha branch

\section{ARTICLE INFO}

\begin{tabular}{l}
\hline Keywords \\
APC \\
Coliform \\
Enteropathogenic E.coli. \\
Ready-to-eat meat \\
products \\
Staphylococcus aureus \\
\hline Received $10 / 10 / 2019$ \\
Accepted $11 / 11 / 2019$ \\
Available On-Line \\
12/05/2020
\end{tabular}

\begin{abstract}
A total of 90 random samples of ready-to-eat meat products (30 of each) of Kofta, Shawerma and Hawawshi samples were collected randomly at different periods of time from various restaurants in Benha city, Qalyubia governorate, Egypt., at different levels of sanitations. Samples were examined for assessment of their bacteriological indices. The mean values of AP Cand. Coliform counts in the examined samples were $5.87 \times 10^{4} \pm 1.14 \times 10^{4} \& 2.17 \times 10^{3} \pm$ $0.39 \times 10^{3}(\mathrm{cfu} / \mathrm{g})$ in Kofta samples; $9.92 \times 10^{4} \pm 2.01 \times 10^{4} \& 5.61 \times 10^{3} \pm 0.82 \times 10^{3}(\mathrm{cfu} / \mathrm{g})$ for Shawerma; $3.64 \times 10^{5} \pm 0.58 \times 10^{5} \& 1.32 \times 10^{4} \pm 0.25 \times 10^{4} \quad(\mathrm{cfu} / \mathrm{g})$ for Hawawshi samples, respectively. While The mean values of Staphylococcus aureus count were $4.59 \times 10^{3} \pm$ $0.73 \times 10^{3}(\mathrm{cfu} / \mathrm{g})$ in Kofta samples, $8.05 \times 10^{3} \pm 1.48 \times 10^{3}(\mathrm{cfu} / \mathrm{g})$ for Shawerma and $2.16 \times 10^{4} \pm$ $0.31 \times 10^{4}(\mathrm{cfu} / \mathrm{g})$ for Hawawshi samples. Also Enteropathogenic E.coli strains wereO26 : H11 , O111 : H2 , O113 : H2 and O127 : H6in Kofta samples;O26 : H11 , O55 : H7, O111 : H2, O114 : H4, O127 : H6and O171 : H2inShawerma;O17 : H18, O26 : H11, O91 : H21, O111 : H2, O124and O127: H6 in the examined Hawawshi samples.
\end{abstract}

\section{INTRODUCTION}

Ready-to-eat (RTE) foods are processed foodstuffs gained popularity in recent times since they can be ingested without further thermal treatments (Rodriquez et al., 2010). Also, RTE and ready-to-use (RTU) foods reflect consumer demand for convenient foods, consumers are looking for RTE foods that are fresh, healthy, safe, nutritious and free of additives (Fang, 2005).

Ready-to-eat meat is especially concern because it can be consumed without further cooking and is known to be excellent growth substrates for pathogenic microorganisms. In addition, ignorance about food borne diseases was considered as important risk factor for contamination of food and existence of food borne bacteria that could cause serious health problems for consumed people (Derbew et $a l$., 2013). The number of microorganisms in raw ingredients introduced in RTE meat sandwiches is important, however, many factors such as processing, handling, storage and display may increase the microbiological contamination of final RTE meat sandwiches at restaurants (Angelidis et al., 2006). Moreover, the presence of specific microorganisms such as Escherichia coli and Staph. aureus in foods attributes to the lack of knowledge on the part of the food handlers about proper hygienic practices. Escherichia coli is heat sensitive so, presence of Escherichia coli could be referred to fecal contamination from the hands of food handlers (Lues et al., 2006).
Escherichia coli was considered as one of the common diarrheagenic bacteria within the family Enterobacteriaceae (Torres et al., 2005). E. coli is a human pathogen worldwide associated with meat and meat products, vegetables and water. It is recognized as a bacterium causing hemorrhagic colitis. Diarrheal diseases linked to $E$. coli infections are characterized by blood, cramping, abdominal pain, fever, nausea, and vomiting (Abongo and Momba, 2009). Staph. aureus intoxication is a worldwide problem where several food poisoning outbreaks were reported due to consumption of meat products contaminated with this organism. Accordingly, the total Staph. aureus count can be taken as index of sanitary conditions under which the meat and its products are manufactured and handled(Potter, 2001). Staphylococcal food poisoning is due to the absorption of staphylococcal enterotoxins preformed in the food and the symptoms of Staphyloccal food poisoning are abdominal cramps, nausea, vomiting, sometimes followed by diarrhea (never diarrhea alone). The onset of symptoms remission is observed after $24 \mathrm{~h}$ (Le Loir et al., 2003).

Therefore, the current study was planned out to assess bacteriological indices of some RTE-meat products in different restaurants in Benha city, Qalyubia governorate, Egypt.

\footnotetext{
* Corresponding author: Prof. Hassan Ahmed Mohamed. Food Hygiene Department, Faculty of Veterinary Medicine, Banha university
} 


\section{MATERIAL AND METHODS}

\subsection{Samples collection}

A total of 90 random samples of RTE products of Kofta, Shawerma and Hawawshi (30 of each) were collected at different periods of time from various restaurants in Benha city, Qalyubia governorate, Egypt. Each sample was put in a separated and detected sterile plastic bag and preserved in an ice box then all collected samples were transferred without undue delay to the laboratory under complete aseptic conditions. The collected samples were subjected to the bacteriological examination.

\subsection{Bacteriological Examination}

2.2.1. Preparation of samples (FDA, 2002):

Twenty-five grams of the sample were weighed and transferred into a sterile homogenizer flask containing 225 $\mathrm{ml}$ of sterile peptone water $(0.1 \%)$. The content of the flask was homogenized for 3 minutes at $14000 \mathrm{rpm}$ then allowed to stand for 5 minutes at room temperature. One $\mathrm{ml}$ from the homogenate was transferred into a separate tube containing $9 \mathrm{ml}$ of sterile peptone water $(0.1 \%)$ from which tenfold serial dilutions were prepared. The prepared samples were subjected to the following examinations:

2.2.2. Aerobic plate count. It was carried out according to ISO (2002).

2.2.3. Coliform count: It was prepared according to ISO, (2004).

2.2.4. Screening for Enteropathogenic Escherichia coli: It was carried out according to FDA (2002).

Identification of Enteropathogenic Escherichia Coli (Mac Faddin, 2000):

The suspected isolates were examined morphologically (ISO, 1995), biochemically (Mac Faddin, 2000) and serologically (Kok et al., 1996).

2.2.5. Enumeration and identification of Staph. aureus: It was carried out according to FDA (2001).

\subsubsection{Statistical analysis:}

The obtained results were statistically evaluated according to Feldman et al. (2003).

\section{RESULTS}

Table (1) showed that APC/g of the examined samples of RTE meat products ranged from $6.7 \times 10^{3}$ to $4.3 \times 10^{5}$ with mean $5.87 \times 10^{4} \pm 1.14 \times 10^{4} \mathrm{cfu} / \mathrm{g}$ for kofta, $8.1 \times 10^{3}$ to $1.5 \times 10^{6}$ with mean $9.92 \times 10^{4} \pm 2.01 \times 10^{4} \mathrm{cfu} / \mathrm{g}$ for Shawerma, $2.9 \times 10^{4}$ to $5.2 \times 10^{6}$ with mean $3.64 \times 10^{5} \pm$ $0.58 \times 10^{5} \mathrm{cfu} / \mathrm{g}$ for Hawawshi. So, Hawawshi was the most contaminated RTE meat product followed by Shawerma and then Kofta samples. This could be attributed to the fact that Hawawshi and Shawerma may receive more handling during preparation as well as addition of spices which may be contaminated with high number of microorganisms.

According to table (2) coliform was detected in Kofta, Shawerma and Hawawshi at rate of $63.33 \%, 73.33 \%$, and $80 \%$, respectively.
From the results given in table (3) it was obvious that Hawawshi samples were the most contaminated RTE meat, followed by Shawerma then Kofta samples.

Table 1 Aerobic plate (count/g) (APC) in the examined samples of ready to eat meat products $(\mathrm{n}=30)$

\begin{tabular}{lccc}
\multicolumn{2}{l}{ eat meat products $(\mathrm{n}=30)}$. & & \\
\hline Meat products & Min. & Max. & Mean \pm S.E $^{*}$ \\
\hline Kofta & $6.7 \times 10^{3}$ & $4.3 \times 10^{5}$ & $5.87 \times 10^{4} \pm 1.14 \times 10^{4}$ \\
Shawerma & $8.1 \times 10^{3}$ & $1.5 \times 10^{6}$ & $9.92 \times 10^{4} \pm 2.01 \times 10^{4}$ \\
Hawawshi & $2.9 \times 10^{4}$ & $5.2 \times 10^{6}$ & $3.64 \times 10^{5} \pm 0.58 \times 10^{5}++$
\end{tabular}

${\mathrm{S} . \mathrm{E}^{*}}^{*}=$ Standard error of mean. $++=$ High significant differences $(\mathrm{P}<0.01)$

Table 2 Incidence of coliform bacteria in the examined samples of ready to eat meat products $(\mathrm{n}=30)$

\begin{tabular}{lccc}
\hline Meat products & No. of examined samples & No. & $\%$ \\
\hline Kofta & 30 & 19 & 63.33 \\
Shawerma & 30 & 22 & 73.33 \\
Hawawshi & 30 & 24 & 80 \\
Total & 90 & 65 & 72.22 \\
\hline
\end{tabular}

Table 3 Coliform (counts/g) in the examined samples of ready to eat meat products $(\mathrm{n}=30)$

\begin{tabular}{lccc}
\hline Meat products & Min. & Max. & Mean \pm S.E \\
\hline Kofta & $1.0 \times 10^{2}$ & $1.1 \times 10^{4}$ & $2.17 \times 10^{3} \pm 0.39 \times 10^{3}$ \\
Shawerma & $1.0 \times 10^{2}$ & $3.8 \times 10^{4}$ & $5.61 \times 10^{3} \pm 0.82 \times 10^{3}$ \\
Hawawshi & $1.0 \times 10^{2}$ & $7.3 \times 10^{4}$ & $1.32 \times 10^{4} \pm 0.25 \times 10^{4}++$ \\
\hline
\end{tabular}

It was obvious from the results demonstrated in table (4) that Enteropathogenic E. coli were isolated from RTE meat products at the highest level from Hawawshi (30\%) followed by Shawerma (26.67\%), then Kofta (16.67\%) samples.

According to table (5) Staph. aureus were detected in $46.67 \%$ of Kofta, $56.67 \%$ of Shawerma, and $60 \%$ of Hawawshi.

Table (6) indicated that the total Staphylococcal count in the examined samples of RTE meat products ranged from $1.0 \times 10^{2}$ to $3.0 \times 10^{4}$ with mean $4.59 \times 10^{3} \pm 0.73 \times 10^{3} \mathrm{cfu} / \mathrm{g}$ for Kofta, $1.0 \times 10^{2}$ to $5.0 \times 10^{4}$ with mean $8.05 \times 10^{3} \pm 1.48 \times 10^{3}$ $\mathrm{cfu} / \mathrm{g}$ for Shawerma and $1.0 \times 10^{2}$ to $9.0 \times 10^{4}$ with mean $2.16 \times 10^{4} \pm 0.31 \times 10^{4} \mathrm{cfu} / \mathrm{g}$ for Hawawshi.

Table 4 Incidence of Enteropathogenic E. coli in the examined samples of ready to eat meat products $(\mathrm{n}=30)$

\begin{tabular}{lccc}
\hline Meat products & No. of examined samples & No. & $\%$ \\
\hline Kofta & 30 & 5 & 16.67 \\
Shawerma & 30 & 8 & 26.67 \\
Hawawshi & 30 & 9 & 30 \\
\hline Total & 90 & 22 & 24.44 \\
\hline
\end{tabular}

Table 5 Incidence of Staphylococcus aureus in the examined samples of ready to eat meat products $(\mathrm{n}=30)$.

\begin{tabular}{|c|c|c|c|}
\hline Meat products & No. of examined samples & No. & $\%$ \\
\hline Kofta & 30 & 14 & 46.67 \\
\hline Shawerma & 30 & 17 & 56.67 \\
\hline Hawawshi & 30 & 18 & 60 \\
\hline Total & 90 & 49 & $\overline{54.44}$ \\
\hline
\end{tabular}

Table 6 Staphylococcus aureus (counts/g) in the examined samples of ready to eat meat products $(\mathrm{n}=30)$.

\begin{tabular}{lccc}
\hline Meat products & Min. & Max. & Mean \pm S.E \\
\hline Kofta & $1.0 \times 10^{2}$ & $3.0 \times 10^{4}$ & $4.59 \times 10^{3} \pm 0.73 \times 10^{3}$ \\
Shawerma & $1.0 \times 10^{2}$ & $5.0 \times 10^{4}$ & $8.05 \times 10^{3} \pm 1.48 \times 10^{3}$ \\
Hawawshi & $1.0 \times 10^{2}$ & $9.0 \times 10^{4}$ & $2.16 \times 10^{4} \pm 0.31 \times 10^{4}++$
\end{tabular}


From the results given in table (7), it was obvious that the serotyping and incidence of enteropathogenic E. coli isolated from the examined samples of RTE meat products were $017: \mathrm{H} 18$ that isolated from Hawawshi (3.33\%); O55:H7 from Shawerma (3.33\%), Also O113:H2 from Kofta $(3.33 \%)$ while O114:H4 was isolated from RTE Shawerma $(3.33 \%)$ and $0171: \mathrm{H} 2$ was isolated from RTE Shawerma (3.33\%). Also. The data obtained in table (7) revealed that the serotyping and incidence of Enterohemorrhagic E. coli isolated from the examined samples of RTE meat products were O111:H2 was isolated from ready to eat Kofta $(6.67 \%)$, Shawerma $(6.67 \%)$ and Hawawshi (10\%) samples; O26:H11 from Kofta (3.33\%), Shawerma $(6.67 \%)$ and Hawawshi $(3.33 \%)$ samples and O91:H21 only was isolated from Hawawshi (3.33\%). Moreover, the serotyping and incidence of Enterotoxigenic $E$. coli isolated from the examined samples were (ETEC) O127 : H6 was isolated from Kofta (3.33\%), Shawerma $(3.33 \%)$ and Hawawshi $(6.67 \%)$, while Entero-invasive (EIEC) $\mathrm{O} 124$ was only isolated from $(3.33 \%)$ of Hawawshi samples.

Table 7 Incidence and serotyping of Enteropathogenic E. coli isolated from the examined samples of ready-to-eat meat products $(n=30)$.

\begin{tabular}{lccccccc}
\hline $\begin{array}{l}\text { Meat status } \\
\begin{array}{l}E \\
\text { c coli }\end{array}\end{array}$ & \multicolumn{2}{c}{ Kofta } & \multicolumn{2}{c}{ Shawerma } & \multicolumn{2}{c}{ Hawawshi } & Strain \\
strains & No. & $\%$ & No. & $\%$ & No. & $\%$ & \\
\hline O17 : H18 & - & - & - & - & 1 & 3.33 & EPEC \\
O26 : H11 & 1 & 3.33 & 2 & 6.67 & 1 & 3.33 & EHEC \\
O55 : H7 & - & - & 1 & 3.33 & - & - & EPEC \\
O91 : H21 & - & - & - & - & 1 & 3.33 & EHEC \\
O111 : H2 & 2 & 6.67 & 2 & 6.67 & 3 & 10 & EHEC \\
O113 : H2 & 1 & 3.33 & - & - & - & - & EPEC \\
O114 : H4 & - & - & 1 & 3.33 & - & - & EPEC \\
O124 & - & - & - & - & 1 & 3.33 & EIEC \\
O127 : H6 & 1 & 3.33 & 1 & 3.33 & 2 & 6.67 & ETEC \\
O171 : H2 & - & - & 1 & 3.33 & - & - & EPEC \\
\hline Total & 5 & 16.67 & 8 & 26.67 & 9 & 30 &
\end{tabular}

\section{DISCUSSION}

According to the results of APC cfu/g recorded for Kofta they were relatively agree to some extent with those obtained by El-Taher-Amna (2009) $\left(5.38 \times 10^{4}\right)$, Saad et al. (2011) $\left(3.92 \times 10^{4}\right)$ and Ibrahim-Hemmat et al. (2014), who found that APC in the examined samples of Kofta was $1.83 \times 10^{4} \pm 0.39 \times 10^{4}$. while, the lower results were recorded by Aly-Samar $(2016)\left(6.41 \times 10^{3}\right) \mathrm{cfu} / \mathrm{g}$. Also, the higher results were recorded by Abd El-Fatah-Rabab (2015) $\left(2.69 \times 10^{5}\right)$ and Hazaa-Wafaa $(2015)\left(8.51 \times 10^{5}\right)$.

Regarding to the examined Hawawshi samples, the result of APC /g was nearly similar to those reported by Sobieh (2014) $\left(2.24 \times 10^{5}\right)$

APC of Hawawshi samples were lower than those obtained by Ismail-Soad $(2006)\left(4 \times 10^{6}\right)$, Ghanem-Shereen (2009) $\left(2.13 \times 10^{7}\right)$ and Hazaa-Wafaa $(2015)\left(6.76 \times 10^{6}\right)$, while higher than those obtained by Aly-Samar $(2016)\left(9.33 \times 10^{3}\right)$ cfu/g.

The hygienic conditions of RTE sandwiches were very poor and may constitute a considerable hazard to human health due to using of low-quality raw materials, sufficient heat treatment and inadequate cleaning and sanitization of utensils (Abd-El-Malek, 2014).
The high number of TBC indicated the poor hygienic conditions during food preparation and serving (Durmaz et al., 2015).

According to the results of Coliform (counts/g)recorded for Kofta they were relatively agree to some extent with those obtained by Abd El-Fatah-Rabab (2015) $(5.5 \times 103 / \mathrm{g})$ and Aly-Samar (2016) $(1.86 \times 103 / \mathrm{g})$. While lower results obtained by Saad et al., (2011) $(5.2 \times 102 / \mathrm{g})$, Sobieh (2014) $(7.9 \times 102 / \mathrm{g})$ and Hazaa-Wafaa (2015) $(9.2 \times 102 / \mathrm{g})$.Also, higher results were recorded by El-Mossalami (2003) $\left(1.9 \times 10^{5} / \mathrm{g}\right)$, Ghanem-Shereen $(2009)\left(4.5 \times 10^{4} / \mathrm{g}\right)$ and $\mathrm{Abd}$ El-Raheem (2013) $\left(2.6 \times 10^{5} / \mathrm{g}\right)$.

While the current results of Coliform (counts/g) for Hawawshi samples were nearly similar to those obtained by Ghanem-Shereen $(2009)\left(1.17 \times 10^{4} / \mathrm{g}\right)$ and Hazaa-Wafaa (2015) $\left(1.12 \times 10^{4} / \mathrm{g}\right)$. The lower results were recorded by Ismail-Soad (2006) $(9.3 \times 10 / \mathrm{g})$, Sobieh $(2014)\left(6.6 \times 10^{3} / \mathrm{g}\right)$, and Aly-Samar (2016) $\left(4.27 \times 10^{3} / \mathrm{g}\right)$, while the higher results were obtained by Al-Tawwab $(2004)\left(5.6 \times 10^{5} / \mathrm{g}\right)$.

Coliform bacteria, mainly fecal coliform are enteric bacteria that naturally inhabit the intestinal tract of human and its presence indicates the presence of fecal or sewage contamination introduced to food via contaminated water and equipment or from the unsanitary environment or via handlers' hands (Pelczar et al., 2005).

It is obvious from the results illustrated in table (4) that the Incidence of Enteropathogenic E. coli of kofta were higher than those obtained by Saad et al. (2011) (10\%), Sobieh (2014) $(13.3 \%)$ and Hazaa-Wafaa (2015) (15\%), while lower than the results recorded byEl-Taher-Amna (2009) (26.67\%), El-Mossalami (2003) (50\%) and Abd El-FatahRabab (2015) (33.3\%).

Moreover, the recorded results of the Incidence of Enteropathogenic E. coli for Hawawshi were nearly similar to the results recorded by Hazaa-Wafaa (2015) (30\%); they were higher than those obtained by Ismail-Soad (2006) $(17.3 \%)$ and Ghanem-Shereen (2009) (20\%) and lower than those obtained by Abdallah and Hassan (2000) (33.3\%), Sobieh (2014) (33.3\%) and Aly-Samar (2016) $(35 \%)$.

The current results given in table (6) show that Staph. aureus $\mathrm{cfu} / \mathrm{g}$ in kofta samples were agree to the results recorded by El-Mossalami (2003) $\left(3.3 \times 10^{3}\right)$, El-TaherAmna (2009) $\left(6.9 \times 10^{3}\right)$ and Abd El-Fatah-Rabab (2015) $\left(2.31 \times 10^{3}\right)$. While the highest results were obtained by $\mathrm{Al}$ Tawwab (2004) $\left(9 \times 10^{4}\right)$.The lowest samples of Staph. aureus in kofta samples were obtained by Saad et al. (2011) $\left(9.14 \times 10^{2}\right)$, Sobieh $(2014)\left(9.35 \times 10^{2}\right)$, and HazaaWafaa $(2016)\left(8.13 \times 10^{2}\right) \mathrm{cfu} / \mathrm{g}$.

The recorded results of Staph. aureus count cfu/g for the examined Hawawshi samples were comparatively similar to those obtained by Al-Tawwab $(2004)\left(7 \times 10^{4}\right)$, GhanemShereen (2009) $\left(8.43 \times 10^{4}\right)$ and Hazaa-Wafaa (2015) $\left(6.11 \times 10^{4}\right)$. The lowest results were recorded by IsmailSoad (2006) $\left(2 \times 10^{2}\right)$, and Sobieh $(2014)\left(8.12 \times 10^{3}\right) \mathrm{cfu} / \mathrm{g}$. The pathogenic strains of E.coli were previously isolated from different RTE meat products by Abd El-Fatah-Rabab (2015), Hazaa-Wafaa (2015), who could identify these pathogenic E.coli strains in different ready to eat meat products. 


\section{CONCULOSIONS}

Therefore, to improve the hygienic status of ready-to-eat meat products, thoroughly washing of hands, especially after using toilets, before handling of cooked meat and after handling raw materials and unsanitary objects with soap and warm water for 20 seconds at least. Also, application and implementation of Hazard Analysis and Critical control point (HACCP) system may be the appropriate solution to ensure quality and safety of ready-to-eat meat products especially during preparation and serving.

\section{REFERENCES}

1. Abd Allah, W.H. and Hassan, A.A. (2000): Sanitary status of some ready-to-eat meat meals in Cairo and Giza Governorates. J. Egypt. Vet. Med. Ass., 60(7): 95-104.

2. Abd El-Fatah-Rabab, R. (2015): Bacteriological status of some ready-to-eat meat and poultry meals in Benha City. M. V. Sc. Thesis (Meat Hygiene), Fac. Vet. Med., Benha Univ.

3. Abd El-Malek, A.M. (2014): Microbiological quality of readyto-eat liver sandwiches (Kibda). Global Veterinaria J., 13(6): 1097-1102.

4. Abd El-Raheem, K.A.M.A. (2013): Microbial quality of cooked meat and Edible offal at street vendors' level. M. V. Sc. Thesis, Meat Hygiene, Fac. Vet. Med., Benha Univ.

5. Abongo, B.O. and Momba, M.N.B. (2009): Prevalence and characterization of Escherichia coli O157:H7 isolates from meat and meat products sold in Amatole District, Eastern Cape Province of South Africa. Food Microbiology J., 26: 173-176.

6. Al-Tawwab, M. (2004):Safety of street vended meat meals exposed to the open environment. M.V.Sc. Thesis Meat hygiene, Fac. Vet. Med., Zagazig Univ.

7. Aly, S.A.H. (2016): Enteric bacteria in street vended meat products, M.V.Sc. Thesis (Meat Hygiene), Fac. Vet. Med., Benha Univ.

8. Angelidis, A.S.; Chronis, E.N.; Papageorgiou, D.K.; Kazakis II, Arsenoglou, K.C. and Stathopoulos, G.A. (2006): Non-lactic acid contaminating flora in ready-to-eat foods A potential food-quality index. Food Microbiol., 23: 95-100.

9. Derbew, G.; Sahle, S. and Endris, M. (2013): Bacteriological Assessment of Some Street Vended Foods in Gondar, Ethiopia. Internet J. of Food Safety., 15:33 - 38.

10. Durmaz, H.; Aygun, O. and Sancak, H. (2015): The microbiological quality of grilled meats (Kebab) and salads consumed in Sanliurfa restaurants. Inter. J. Sci. Technol. Res., 1(1): 297:302.

11. El-Mossalami-Eman, K. (2003):Risk assessment of ready prepared meat products. Ph. D., Thesis, Fac. Vet. Med., Cairo Univ.

12. El-Taher-Amna, M. (2009): Impact of temperature abuse on safety of food offered in a University Student Restaurant. M.V.Sc. Thesis, Meat Hygiene, Fac. Vet. Med., Benha Univ., Egypt.

13. Fang, T.J. (2005): Bacterial contamination of ready-to-eat foods: concern for human toxicity. Reviews in food and nutrition -toxicity.,4:143-171.

14. FDA "Food and Drug Administration" (2001):Staphylococcus aureus. Bacteriological analytical manual .8th Ed. Chapter12. Academic Press, Gaithersburg, UK.

15. FDA (2002): Enumeration of coliform bacteria and identification of E. coli. In Bacteriological Analytical Manual.
Center for Food Safety and Applied Nutrition, Department of Health and Human Searches 8th ed. US FDA, Chapter 4.

16. Feldman, D.; Ganon, J.; Haffman, R. and Simpson, J. (2003):The solution for data analysis and presentation graphics. 2nd Ed., Abacus Lancripts, Inc., Berkeley, USA.

17. Ghanem-Shereen, H. A. (2009): Microbiological status of some ready-to-eat meat products. M. V. Sc., Thesis (Meat Hygiene), Fac. Vet. Med., Benha Univ.

18. Hazaa-Wafaa, M.A.A (2015): Bacterial hazards associated with consumption of street vended meat products in Kalyobia governorate. M. V. Sc. Thesis (Meat Hygiene), Fac. Vet. Med., Benha Univ.

19. Ibrahim-Hemmat, M., Amin-Reham, A. and Sobieh A. S (2014): Bacteriological evaluation of fast foods at restaurants level in Cairo governorate", Benha Vet. Med. J., 26(1):34-42.

20. Ismail-Soad, A . (2006): microbiological quality of hawawshi consumed in Ismailia, Egypt. J. Food Safety., 26: 251-263.

21. ISO (International Standards Organization) (1995): Microbiology of food and animal feeding stuffs. ISO 10272: 1995 (E) International Standards Organization, Geneva.

22. ISO (International Standards Organization) (2002): Horizontal method for enumeration of microorganisms, colony count technique at $30{ }^{\circ} \mathrm{C}$. International Standards Organization, Geneva.

23. ISO (2004): Microbiology of food and animal feeding stuffs Horizontal method for detection and enumeration of Enterobacteriaceae, Part 2: colony count method. International Standards Organization, Geneva.

24. Kok, T.; Worswich, D. and Gowans, E. (1996): Some serological techniques for microbial and viral infections. In Practical Medical Microbiology (Collee, J.; Fraser, A.; Marmion, B. and Simmons, A., eds.), 14th ed., Edinburgh, Churchill Livingstone, UK.

25. Le Loir, Y.; Baron, F. and Gautier, M. (2003): S. aureus and food poisoning. Genetics and Molecular Research., 2 (1): $63-$ 76.

26. Lues, J.; Rasephei, M.; Venter, P. and Theron, M. (2006): Assessing food safety and associated food-handling practices in Street food vending. Int. J. Enviro. Heal. Res., 16: 319-328.

27. Mac faddin, J. F. (2000): Biochemical tests for identification medical bacteria. Warery Press, INC. Baltimore, Md. 21202 USA.

28. Parveen, S.; Das, S., Begum, A.; Sultana, N.; Hoque, M.M. and Ahmad, I. (2014): Microbiological quality assessment of three selected spices in Bangladesh. J. Intern. Food Research., 21 (4): 1327-1330.

29. Pelczar, M.J.; Chan, E.C.S. and Noel, R.K.C. (2005): Microbiology ( $5^{\text {th }}$ Ed.), Tata mc Graw Hill, New Delhi. Pp. 571.

30. Potter, N.N. (2001): Food Science. 3rd Ed. The AVI Publishing Co., INC. New York, USA.

31. Rodriquez, C.; Gamboa M; del, M. and Arias, M.L. (2010): Microbiological evaluation of ready-to-eat foods manufactured by small Costa Rican industries. Arch Latinoam Nutr., 60(2):179-183.

32. Saad, M.S.; Ibrahim-Hemmat, M. and Ali-Enas A.M. (2011): Microbial and chemical evaluation of fast food. J. Benha Vet. Med.; (1):44-51.

33. Sobieh, A.S.A. (2014): Fast meat meals safety at restaurants level in Cairo governorate. M. V. Sc. (Meat Hygiene) Fac. Vet. Med., Benha Univ.

34. Torres, A. G., Zhou, X. and Kaper, J.B. (2005): Adherence of diarrheagenic Escherichia coli strains to epithelial cells. Infect. Immun., 73: 18-29. 